\title{
Kernos
}

Revue internationale et pluridisciplinaire de religion grecque antique

$28 \mid 2015$

Varia

\section{The Documents in Sokolowski's Lois sacrées des cités grecques (LSCG)}

\section{Edward Harris and Jan-Mathieu Carbon}

\section{(2) OpenEdition \\ Journals}

\section{Electronic version}

URL: http://journals.openedition.org/kernos/2373

DOI: 10.4000/kernos.2373

ISSN: 2034-7871

\section{Publisher}

Centre international d'étude de la religion grecque antique

\section{Printed version}

Date of publication: 1 October 2015

ISBN: 978-2-87562-055-2

ISSN: 0776-3824

Electronic reference

Edward Harris and Jan-Mathieu Carbon, «The Documents in Sokolowski's Lois sacrées des cités grecques (LSCG) », Kernos [Online], 28 | 2015, Online since 01 October 2015, connection on 01 May 2019. URL : http://journals.openedition.org/kernos/2373; DOI : 10.4000/kernos.2373 


\section{The Documents in Sokolowski's Lois sacrées des cités grecques (LSCG)}

This list of the documents found in Lois sacrées des cités grecques attempts to classify them in terms of the categories formulated in Harris, "Towards a Typology" (2015).

\section{Attica. Athens. Calendar (probably subdivision of the polis) - early fifth century BCE (IG $\left.\mathrm{I}^{3} 234\right)$}

The inscription is damaged, but contains the names of months (line 3: Thargelion; line 16: Gamelion), the names of gods, and animals to be sacrificed. The authority cannot be identified, but the non-standard sequence of months and brief entries suggest a calendar of a subdivision of the polis.

\section{Attica. Athens. Calendar (probably subdivision of the polis) - early fifth century BCE (IG $\left.\mathrm{I}^{3} 246\right)$}

The inscription is very fragmentary, but contains dates (line A5: 6 Thargelion; line A10: Skirophorion), the names of gods (lines A9-10: Athena), and sacrificial offerings. According to von Prott, this calendar could have belonged to a tribe, phratry or another association. The abbreviated style, similar to that of no. 1, with only two sacrifices in Thargelion may also suggest a subdivision of the polis.

3. Attica. Acropolis. Law/decree about sacred matters (polis) 485/4 BCE (if the restoration of the archon Philokrates is correct) $\left(I G \mathrm{I}^{3} 4\right)$

This is a decree/law of the Assembly (lines 26-7) and provides rules about conduct on the Acropolis in casuistic form (lines 11-13; 15-17; 23-25). The treasurers have the right to impose fines for infractions (lines 6-8, lines 11-13, 15-16) and so does the prytanis (lines 22-3). All the regulations pertain to the maintenance of sanctuary buildings on the Acropolis. See Butz (2010). 


\section{Attica. Decree about sacred matters (polis) - around $500 \mathrm{BCE}$ $\left(I G \mathbf{I}^{3} 5\right)$}

This is a decree of the Assembly (line 1 has a simple enactment formula) and gives orders to the bieropoioi about sacrifices at the festival of the Eleusinia. The text is completely preserved, and appears in abbreviated form. The hieropoioi underwent euthynai and could be punished for any infractions under that procedure. See Clinton IE 13.

\section{Attica. Eleusis. Decree about sacred matters (polis) - 440-435 BCE (IG $\left.\mathrm{I}^{3} 78 \mathrm{a}\right)$}

This is a decree of the Assembly (lines 2-3 contain an enactment formula) about the aparche to be paid to Demeter and Kore according to the oracle at Delphi (lines 4-5). There are numerous instructions to officials and fines imposed on officials. There are two rules including fines in a casuistic form (lines 18-21; 57-59); the rest are orders in the prescriptive form. For detailed discussion see Cavanaugh (1996) and Clinton IE 28a.

\section{Attica. Eleusis. Uncertain - end of the fifth century BCE (IG $\mathrm{I}^{3}$ 251)}

The inscription is too fragmentary to allow firm conclusions. Sokolowski thought that wood for sacrifices is mentioned in line 5-7. Clinton (IE 22) believes that this is a law/decree.

\section{Attica. Eleusis. Calendar (deme of Eleusis?) - after $330 \mathrm{BCE}$ $\left(I G \mathrm{II}^{2} 1363\right)$}

This is a calendar: it contains dates (lines 3, 8), mention of priests and priestesses, festivals (line 7: Proerosia; line 17: pannychis) and gods. There are several amounts of money in the margin (lines 7, 9, 21). For discussion, see Clinton IE 175.

\section{Attica. Athens. Decree about sacred matters (polis) - ca. 220 $\mathrm{AD}\left(I G \mathrm{II}^{2}\right.$ 1078; Clinton IE 638)}

This is a decree of the Assembly (enactment formulas in lines 1-3, 9). Orders are given to the kosmetes of the ephebes to lead a procession as part of the 
Eleusinian Mysteries (lines 7-9). These are general orders in the prescriptive form. There are no penalties listed, but all the officials involved are subject to euthynai.

\section{Attica. Vari. Sign (private individual or association) - third quarter of fifth century BCE $\left(I G \mathrm{I}^{3} 978,982\right)$}

This is a sign: it contains orders about entrails and dung, but does not name an authority. Inscriptions from the Vari cave indicate however that the shrine was a private dedication made by Archedemus of Thera to the Nymphs (IG i3 977 , 978, 980 with discussion by K. Hallof, in Schörner and Goette [2004], 42-4, 50, 51-54), but there were others who contributed to the cult. On the dossier of documents from the cave, see Purvis (2003), 33-53.

\section{Attica. Athens. Law/decree about sacred matters (deme) - before $460 \mathrm{BCE}\left(I G \mathrm{I}^{3} 244\right)$}

This appears to be a series of rules (possibly a dossier of texts) about the distribution of meat from the deme of Skambonidai (lines A19-20; B5-6; C 9$10)$; the precise arrangement is unclear and was not necessarily calendrical. A magistrate (euthynos) (lines B8-10; 19-20) is named. There may be a rule in casuistic form (lines A5-6). These two features do not confirm, but also do not completely rule out, the possibility that the inscription is a calendar.

\section{Athens. Found at Chalkis. Law/decree about sacred matters (deme or other group?) - around $421 \mathrm{BCE}\left(I G \mathrm{I}^{3} 255\right)$}

Wilhelm (1902), 135ff., attributed the list to a trittys. Side A has a list of sacrifices; Side B has a list of portions given to priests. This was possibly a dossier of texts, cp. above no. 10 .

\section{Attica. Athens. Laws/decrees about a priesthood (polis) - Part I around $448 \mathrm{BCE}$; Part II around $420 \mathrm{BCE}\left(I G \mathrm{I}^{3} 36\right)$}

These are two decrees. Part A is a decree of the Assembly, which creates a priesthood for Athena Nike. It gives her a salary (line A9), and honors from the sacrifice (lines A10-11). There are orders to build a sanctuary and an altar. Part $\mathrm{B}$ gives the salary again, which is to be paid by the kolakretai. See Blok (2014). 


\section{Attica. Athens. Law/decree about sacred matters (polis) - 421/0 BCE (IG $\left.\mathrm{I}^{3} 82\right)$}

This is a decree of the Assembly (enactment formula in lines 2-5) and gives many orders in the prescriptive form to officials about the Hephaistaia. There is a rule in casuistic form: the bieropoioi have the right to impose a fine of up to fifty drachmas if anyone is disorderly; for larger sums the case goes before the court (lines 26-30). Despite enactment by the Assembly, the Council retains authority about certain matters (lines 39 and 44).

\section{Attica. Athens. Decree about a shrine (polis) - 418/7 BCE (IG $\left.I^{3} 184\right)$}

This is a decree of the Assembly (enactment formula in lines 2-4) and instructs various officials (basileus, poletai, to fence off and lease the temenos of Kodros, Neleus, and Basile. There is a penalty for the Council and the Basileus if they do not carry out the orders (lines 9-11, 18-20). The terms of the contract are spelled out (lines 30-38). Strictly speaking, the decree relates to renting out land and construction, not to the performance of rituals even though the income is used for rituals.

\section{Attica. Athens. Law/decree about sacred matters (polis) - late fifth century BCE $\left(I G \mathrm{I}^{3} 7\right)$}

This is a law (enactment formula lines 1-3) granting permanent privileges to the genos of the Praxiergidai and the right to include them in their dossier. The inscription contains three parts: 1) the decree of the people about the publication of the text (lines 3-9), 2) the oracle of Apollo about the role of the Praxiergidai (lines 10-12), and 3) the ancestral privileges of the Praxiergidai (lines 13-25). A peplos, probably for the statue of the goddess, is mentioned. This confirms the privileges of a private group, probably in a public ritual. See Parker (1996), 124-5; Harris (2006), 59 n. 54.

\section{Attica. Athens. Calendar (polis) - end fifth-early fourth century $\mathrm{BCE}\left(I G \mathrm{I}^{3} 238\right)$}

This is a calendar with a list of offerings to be made to gods with an amount of money in the margin (line 6). The inscription mentions Oenoe; Sokolowski considered this a fragment of the fasti of the deme of Oenoe. Lambert (2002), 
face A, fr. 12, properly includes it as part of the civic sacrificial calendar of Athens.

\section{Attica. Athens. Calendar (polis) - end fifth-early fourth century BCE (IG I $\left.I^{3} 241\right)$}

Very fragmentary. There is the name of a festival (line A17), the name of a god (line A5), and sacrificial animals. There is an amount of money in the margin (line 10). Lambert (2002), faces A-B, fr. 1, properly includes this as part of the civic sacrificial calendar of Athens.

\section{Attica. Erchia. Calendar (deme) or accounts of demarch - first half of fourth century BCE (SEG 21: 541; 22: 131)}

This appears to be a calendar with sacrifices listed by months for the deme of Erchia, which is divided into five columns for the purposes of accounting. It contains the heading $\Delta \eta \mu \alpha \varrho \chi^{i \alpha} \dot{\eta} \mu \dot{\varepsilon} \zeta \omega \nu$, which would appear to indicate that the deme was the authority that set up the calendar. For the meaning of this phrase, see Whitehead (1986), 194-199.

\section{Attica. Athens. By-laws (private association) - early fourth century BCE (Syll. ${ }^{3}$ 221; IG $\mathrm{II}^{2}$ 1237)}

These are rules issued by a phratry, a private group. Sokolowski only reproduces lines $1-8$. The rest is a dossier containing different rules about the procedures of the phratry. Lines 9-58 contain rules about procedures for admission to the phratry and appeals against adverse decisions. Instructions are given to the officials of the phratry, and there are penalties on these officials for not imposing fines (lines 26, 42, 48-50, 57-58). Lines 68-113 provide a rider to the previous rules and penalties for a thiasos within the phratry that puts forward a candidate who is rejected, with penalties in drachmas. Lines 114-125 contain rules concerning prior notification to the phratry about candidates being proposed for membership. For discussion, see Hedrick (1990) and on phratries in general see Lambert (1998). For text and translation see Rhodes and Osborne (2003), 26-39 (= GHI 5). 


\section{Attica. Athens. Calendar of Marathonian Tetrapolis (sub- division of the polis) - 375-350 BCE (?) (IG $\left.\mathrm{II}^{2} 1358\right)$}

The stele is inscribed on two sides. Face A contains two columns. The first column is not preserved on the left but appears to contain the names of months, the names of animals to be sacrificed, and amounts of money. The second column contains sacrifices by the Marathonians (lines 1-53); the word demarchos has been restored in line 1. This column contains the names of months, animals to be sacrificed, amounts of money, and amounts for the bierosyna. Line 54 indicates that a list of sacrifices by the Trikorynthians followed. Dow plausibly suggested that the names and amounts of money on Face B, of which little remains, were contributions made by individuals for the sacrifices on Face A. For a new text and detailed discussion, see Lambert (2000).

\section{Attica. Piraeus. Signs - fourth century BCE (IG $\left.I^{2} 4962\right)$}

This is a block of marble inscribed on three sides; it was inscribed in at least three phases. Lines 1-10 of Face A were inscribed in the fourth century BCE and list sacrifices (prothymata) of popana, which are depicted on the stele, to Maleatas, Apollo, Hermes, Iaso, Akeso, and Panakeia. Lines 11-17 of Face A indicates that the stelai were dedicated by Euthydemus of Eleusis, a priest of Asclepius, and placed in front of the altars with the instructions. The placement of this sign is thus consistent with the placement of other signs-see Harris (2015), 59. Euthydemus is attested in other inscriptions (LSS 11, line 2; Syll. ${ }^{3}$ 1048; IG II 21194 , lines 11 and 17). Still later texts appear on the other faces: Face B lists sacrifices to Helios and Mnemosyne, and Faces B and C mention three altars. Face D contains one word (nephalio $)$.

\section{Attica. Piraeus. Sign - fourth century BCE (IG II $\left.{ }^{2} 4971\right)$}

There is an order to give three aresteras (propitiatory offerings) to the Fates and three keria. This is a sign.

\section{Attica. Piraeus. Sign - fourth century BCE (IG $\left.\mathrm{II}^{2} 4970\right)$.}

Sokolowski noted that the genitive of Artemis would indicate that this concerns an altar or a sanctuary. Two sacrifices of three monomphala are to be made (lines 3, 5-6). Sokolowski suggests the second is to Leto. 


\section{Attica. Acropolis. Sign - third or second century BCE (IG $\mathrm{II}^{2}$ 4986).}

This is found on an altar from the Acropolis and and labelled with the genitive of the name of Herakles. Sokolowski connects it with the sanctuary of Asclepius. This must be a sign; it contains an order to sacrifice three monomphala.

\section{Attica. Acropolis. Sign - fourth or third century BCE (IG $\mathrm{II}^{2}$ 4989)}

Two short inscriptions found on altars on the south side of the Acropolis. Each indicates it belongs to Apollo Pythios and contains an order to sacrifice three cakes (bebdomos bous, with Pollux 6.76).

26. Attica. Athens. Sign - (SEG 21: 786)

This is similar to no. 21 .

\section{Attica. Acropolis. Sign - (IG $\left.\mathrm{II}^{2} 4988\right)$}

This is heavily restored but appears to resemble nos. 23 and 24 .

\section{Attica. Athens. Accounts (sub-division of the polis) - fourth century BCE (IG II 1356 with $S E G 54: 214$ for new fragments)}

The inscription records payments to priestesses (lines 5, 9-10, 11-2, 16, 19, 20, 23-34, 26-27, 28, 31). Given the findspot (Glyphada), the accounts probably belong to the deme of Aixone. Lines 36-37 read ö $\tau \alpha \nu \delta \dot{\varepsilon} \tau \iota \varsigma \tau \tilde{\omega} \nu \pi \varepsilon \nu \tau \eta \varkappa O \sigma \sigma \tau u ́ \omega \nu$ túnı, "when one of the pentekostyes sacrifices": this therefore suggests that the authority issuing the accounts oversaw and was greater than the multiple divisions of the pentekostyes. For discussion of the term pentekostys in this context, see Steinhauer (2004), 167-173, and Ackermann (2011), 39-78. 
29. Attica. Athens. Accounts (sub-division of the polis?) - middle of the fourth century BCE (IG $\left.\mathrm{II}^{2} 1359\right)$

This is similar to the preceding and the authority issuing the document is unclear. A distinction is made between biereiosyna (portions of sacrificial animals) and katarche (cash payment).

\section{Attica. Athens. Uncertain (polis or deme?) - fourth century BCE (IG II $\left.{ }^{2} 1360\right)$}

The document is concerned with portions of sacrificial animals to distribute. A board of epimeletai is mentioned in line 9. It is impossible to know which authority issued these orders.

\section{Attica. Acropolis. Decree about sacred matters (polis or tribe?) - fourth century BCE (IG $\left.\mathrm{II}^{2} 1146\right)$}

This is very fragmentary but appears to be part of a decree. There is the formula for the proposer, but not the other parts of a prescript, yet lines 4-5 mention prayers for the good fortune of the Council (restored) and people but also the tribe of Erechtheis. A board of epimeletai is mentioned in line 12.

\section{Attica. Athens. Law/decree about sacred matters (polis) - 352/1 BCE (IG II $^{3}$ 292; Rhodes and Osborne, GHI 58)}

This is a decree about the Sacred Orgas and the consultation of Delphi but the prescript is missing. It combines some one-off measures about setting the boundaries of the orgas (lines 5-16, 65-84) and consultation of the Delphic oracle (lines 23-54), but also general rules about policing the orgas (lines 16-23). There are also orders for publication (lines 54-57).

\section{Attica. Athens - Law about sacred matters (polis) - 335/4- 330/29 BCE (IG II ${ }^{3}$ 447; Rhodes and Osborne, GHI 81)}

This is a law (nomos) enacted by the nomothetai (line 7) and contains rules about the poletai leasing the Nea and collecting the pentekoste (lines A7-18). The funds collected are for the annual Panathenaea (lines A19-20). There follow rules about sacrifices and the officials performing them, and the distribution of meat 
(lines B1-27). The bieropoioi are to supervise the pannychis and the procession and have the power to impose fines (lines B27-35).

\section{Attica. Athens. Decree granting engktesis ges (polis) - 333/2 BCE $\left(I G I^{3} 337\right)$}

This decree grants the citizens of Kition in Athens who have made a

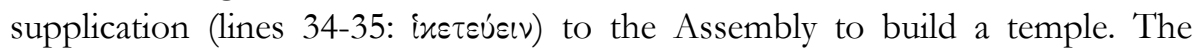
actual decree has nothing to do with religious activity except indirectly and grants merchants from Kition the right of engktesis ges, which is purely civic and legal (see Peçirka 1966). They use this right to construct a shrine, but the right could be used to build non-religious structures.

\section{Attica. Athens. Decree about statue of goddess and sacrifice (polis) - between 336 and $330 \mathrm{BCE}\left(I G \mathrm{II}^{3} 444\right)$}

This decree contains orders for repairs to the statue of Athena Nike. This is a decree and gives one-off instructions. There is also an order about making a sacrifice (lines 18-19: $\left.\dot{\alpha} \varepsilon\left[\sigma \tau \eta_{\varrho} \iota \iota \nu\right]\right)$, possibly on the advice of an exegetes (lines 19-20), but this does not establish a permanent rule. Lines 30-34 are fragmentary but contain praise for a sculptor from Boiotia.

\section{Attica. Piraeus. Law/decree about sacred matters (deme) - fourth century BCE $\left(I G \mathrm{II}^{2} 1177\right)$}

This is a deme decree (lines 12-3 contain an enactment formula) and lays down rules about what can and cannot be done in the Thesmophorion. The demarch is responsible (lines 2-3) and has the power to impose fines and bring cases into court (lines 14-17); this contains a rule in casuistic form. The horistai in line 22 are presumably deme officials. This is a law in the sense of a permanent enactment.

\section{Attica. Athens. Rules given by priest on the basis of a decree of the Assembly - end of the fourth century BCE (IG $\left.I^{2}{ }^{2} 1362\right)$}

This is an unusual inscription because it begins with a set of prohibitions issued by the priest of Apollo Erithaseus (lines 2-7). There follows a rule in casuistic form prescribing penalties for slaves (lines 7-13) and for free persons (lines 14- 
17). The fines are to be collected by the priest acting in conjunction with the demarch (line 15). The priest is also to report all offenses to the basileus and the Council (lines 12,17). Even though the inscription does not take the form of a decree but contains a priestly prohibition, the priest acts on the authority of a decree of the Council and Assembly (lines 12-13, 17-18).

\section{Attica. Athens. Law/decree (polis?) and law/decree (deme) - end of the fourth century $\mathrm{BCE}\left(I G \mathrm{II}^{2} 1195\right)$}

The principal (second) text on the stone is a decree of the deme Kollytos and contains an enactment formula (line 10; prescript in lines 6-10). The first five lines on the stone contain the fragments of another text, in the form of a publication formula for a decree of the people (so Sokolowski). Because the first part of that inscription is not preserved, it is in fact impossible to determine the relationship between the two measures; it is possible (but uncertain) that the deme was acting in accordance with instructions from the Assembly.

\section{Attica. Athens. Law/decree about sacred matters (polis) - around 283/2 BCE (IG $\left.\mathrm{II}^{3} 879\right)$}

This is a decree of the Assembly (enactment formula at lines 2-20 including the decree of the Council) instructing the astynomoi to purify the temple for the procession of Aphrodite Pandemos (lines 20-24) and to clean the altars and put pitch on doors (lines 24-28). These are officials who have civic duties being assigned duties relating to religious activities (but not carrying out sacrifices). This is a law in the sense of a permanent enactment.

\section{Attica. Asklepieion. Law/decree about sacred matters (polis) - 268/7 BCE (IG II $^{3}$ 914)}

This is a fragment of a decree of the Assembly (the preserved lines contain a lengthy enactment formula), but it qualifies as a law about sacred matters because it lays down general rules about public doctors sacrificing to Asclepius and Hygeia twice a year (lines 11-13). The section that is not preserved appears to have laid down rules for a priest (lines 18-19). 


\section{Attica. Athens. Decree containing order to melt down dedications and construct a dedication for a god (polis) - 220/19 BCE (IG $\left.\mathrm{II}^{3} 1154\right)$}

This is an order of the Assembly and calls for election of two men from the Areopagus and three others to supervise the melting down of dedications in the sanctuary of the Heros Iatros in conjunction with the priest, the general for the paraskene_and the architect for shrines (lines 25-34). The dedications are to be made into an oinochoe for the god (lines 19-20). The names of those who dedicated are also to be written down and the weights of their dedications (lines 37-40). The names of those elected are recorded (lines 49-53). This type of order to melt down dedications was given the technical name kathairesis. On orders of the Assembly to melt down dedications, see Dem. 22.69-73, IG II ${ }^{2}$ 216, lines 13 and 17; 217, line 13, with D. Harris (1995), 31-36. Even though the inscription records a decree and accounts, it is published as a dedication to the god (lines 1-4). The items melted down, their weights and their dedicators are recorded (lines 54-88). This is not a law because it contains instructions for one occasion.

\section{Attica. Athens. Decree containing order to melt down dedications and construct a dedication for a god (polis) - second century BCE (IG $\left.\mathrm{II}^{2} 840\right)$}

This is similar to the previous decree (no. 41), but is a decree of the Council (lines 17-19; cf. lines 29-30, which mention the Council and People). In this case, those elected are to take worn out items and make news ones. There are to be three men elected as in. no. 41, but this time also three men from the Council (lines 8-9, 18), in order to melt down items to be placed in the Metroon (line 24).

\section{Attica. Athens. Fragment with an order to a priest (polis?) - second century BCE (IG $\mathrm{II}^{2}$ 995)}

A priest is given the power to move dedications and dedicatory plaques so that the view of the statue is not blocked (lines 5-10). In the future all who dedicate must obtain approval of the priest (lines 10-12). This grants powers to a priest but does not prescribe rituals to be performed. 


\section{Attica. Athens. Decree containing order to repair a shrine (polis) - 52/51 BCE (IG II ${ }^{2}$ 1046; Syll. $\left.{ }^{3} 756\right)$}

This is a fragmentary decree of the Council and Assembly, but contains mainly the decree of the Council (lines 5, 7, 19). The priest of Asclepius and Hygeia, Diokles approached the Council and reported on the dilapidated condition of a temple (lines 10-14) and asked for permission to repair it from his own funds (lines 14-18). The Council grants permission and instructs that an inscription commemorating his generosity be set up (lines 22-30). This is a one-off set of orders and concerns repairs to a building, not religious activity.

\section{Attica. Piraeus. By-laws (private association) - fourth century BCE (IG II $\left.{ }^{2} 1361\right)$}

This is a by-law (tonde ton nomon, line 13) issued by the orgeones of the Bendis and indicates contributions to be made. The orgeones vote about collective activities (lines 11-12) and meet on the second day of each month (lines 16-17). There is also an entrenchment clause with a fine mentioned (lines 13-14).

\section{Attica. Piraeus. By-law (private association), mentioning decree (of Assembly) - first half of third century BCE (IG $\mathrm{II}^{2}$ 1283)}

This is a by-law of the Thracian orgeones of Bendis of the Piraeus (enactment formula at line 13), but refers to a law of the Assembly giving the orgeones the right of engktesis (lines 4-6), and to an oracle from Dodona (line 6). The measure also refers to a law instructing the Thracians to conduct a procession from the Prytaneion to the Piraeus (lines 10-13). The by-law contains instructions to the priest and priestess about prayers during sacrifices, which follow the ancestral rules of the Thracians and the laws of the city (lines 20-27). This law is to some degree similar to the one about the Praxiergadai, with the polis recognizing the rights of a group (no. 15, above). The orgeones of the Piraeus wish to accept the orgeones of the city and pass this by-law to respect the city's wish that both groups of orgeones cooperate (lines 9-10). On the orgeons of Bendis, see Wijma (2014) 126-155. 


\section{Attica. Athens. Lease (private association) - 307/6 BCE (IG $\mathrm{II}^{2}$ 2499)}

The orgeones lease the shrine of Egretes for ten years to Diognetus, the son of Arcesilaus for ten years (lines 2-4). This is a contract, not a by-law. The lessee is required to perform certain actions and make regular payments of rent (lines 530). The lease is void if he fails to make regular payments (lines 30-37).

\section{Attica. Athens. By-law (private association, A) and honorary decree (private association, B) - A around 183/2 BCE; B around 175/4 BCE (IG II $\left.^{2} 1328-29\right)$}

The first text is a by-law, which lays down rules for a priestess and sets a fine of up to fifty drachmas if she does not obey (lines A9-11) and a prohibition against proposing or putting to the vote a motion of praise (lines A11-12). There appears to be a penalty in lines 12-13, but the meaning is uncertain. There is also a rule against continuatio (lines A14-16) with a penalty. The second decree is in honor of Metrodora, who is made zakora for life (lines B19-21). There is mention of a trial involving Metrodora (lines B4). This is therefore a dossier containing two kinds of documents.

\section{Attica. Piraeus. Honorary decree concerning priesthood (private association) - around 176/5 $\mathrm{BCE}\left(I G \mathrm{II}^{2} 1326\right)$}

The document begins by reproducing an honorary decree of the Dionysiasts for Dionysius, who is praised for his numerous services (lines 4-21; cf. IG II ${ }^{2} 1325$ ). In recognition of his father's services, the association grants his son Agathocles the priesthood and the same honors as his father held (lines 34-38). There is an allusion to a law (nomos) of the orgeones (lines 23-24, 31, 45). This appears to be a one-off measure, not a by-law meant as a general rule, but the measures indirectly referred to as a nomos would qualify as by-laws of a private association.

50. Attica. Teithras. Decree about sacred matters (Council, A) and dedication (private, B) - first half of first century BCE (SEG 22: 114; 23: 77)

This is a decree of the Council about the cult of Isis. There are rules laid down, one with a penalty against continuatio in office in casuistic form (lines 10). Those 
wishing to make dedications must obtain permission of the Council (lines 12-4). Text $\mathrm{B}$ is an example of such a private dedication, inscribed below the decree.

\section{Attica. Athens. By-laws (private association) - before $178 \mathrm{CE}$ $\left(I G I^{2} 1368\right)$}

These are by-laws of a private group of Iobacchoi, but also contain an account of various past meetings of the association (lines 11-31). There are officials and fines. The possibility of exclusion is also mentioned.

\section{Attica. Athens. Calendar (private association?) - first century CE (IG II $\left.{ }^{2} 1367\right)$}

This is a calendar: it has the names of months (lines 1, 4, 9, 11, 16, 21, 22, 23, 26) with offerings to gods. Sokolowski thinks it belongs to a private association. The fact that the sacrifices occur only sporadically and on a few months does indeed point away from a calendar of the polis or a deme.

\section{Attica. Hymettus. By-laws (private association) - second century CE (IG $\left.\mathrm{II}^{2} 1369\right)$}

This is actually called a "law of the eranistal" (line 30: nomos; line 29: thesmos). It requires an examination before being admitted to the group (lines 31-36). There is a rule in casuistic form: if anyone causes brawls or noise, he is to be thrown out and fined 25 Attic drachmas or receive fifty lashes (lines 40-44). No distinction appears to be made between free persons and slaves.

\section{Attica. Find spot unknown. Sign - first century CE $\left(I G \mathrm{II}^{2}\right.$ 1364)}

This was placed at a shrine of Asclepius and Hygieia (lines 1-3) and requires farmers and neighbors to sacrifice to gods (lines 4-6). There is a prescription about giving a share to the founder and the theokolos (lines 7-9) and a prohibition against taking away meat (lines 10-11). Sokolowski thinks this is private cult: this is possible. The sign indicates the presence of some form of authority over the cult. 


\section{Attica. Sounion. Dedication and by-laws (private association) - second century $\mathrm{CE}\left(I G \mathrm{II}^{2} 1365\right)$}

Xanthus has set up a cult of Men and prescribes rules about his cult, notably purity rules. No one should sacrifice without the founder, and if one violates the rule, the sacrifice is not received by the god (lines 7-9). For other infractions, the offender has offended the god, whom he cannot appease (lines 14-16). For the term hamartia as an offense against the god Men, see also SEG 38: 1237.

\section{Kleonai. Law/decree about sacred matters (polis?) - Archaic period (Jeffery, LSAG 405, no. 1)}

The inscription contains rules about pollution (lines $5,8,11$ ) and purification (lines 11-12 34-14) presented in a casuistic manner, but there is no explicit indication of the authority. However, there is mention of a law (line 14), and the mention of a publicly funded sacrifice (lines 15-16) would appear to indicate that the polis was the authority behind the rules.

\section{Argos. Law/decree about sacred matters (?) (polis) - Hellenistic (IG IV 557)}

This appears to be the decision of an assembly (line 2: edoxe) about the temple of Apollo Lykeios (Paus. 2.19.3). It is hard to tell if penalties are imposed. If the restoration [strat] agoi (line 9) is correct, these generals should be public officials.

\section{Kalaureia. Dedication and by-laws (private?) - third century BCE (IG IV 840)}

This is a dedication of money ( 300 drachmas) for sacrifices to Poseidon and Zeus Soter. Poseidon is the god of the Kalaurian amphictyony and had a temple at Kalaureia. There are officials (epimeletal) mentioned who are to administer the funds (lines 10-11). There is no overt mention of the control of the polis over this donation, by contrast with no. 59 . 
59. Kalaureia. Law/decree about administering a donation made by private individuals for sacrifices (polis) - third century BCE (Syll. ${ }^{3}$ 993)

This is a decree enacted by citizens (line 2) and appoints overseers (lines 4-5, 22-23) for the money and land dedicated by Agasicles and Nikagora (lines 4-8). Even though the money comes from a private individual, officials from the city administer it. Two epimeletai are to lend the funds on real or personal security (lines 5-8) and to rent out the land (lines 8-10).

60. Epidauros. Law about sacred matters (polis or sanctuary?) end of the fifth century BCE $\left(I G I V^{2} 1,40\right)$

This regulation prescribes sacrifices to Apollo (lines 1-17) and to Asclepius (lines 18-34). Officials called hiaromnamones are involved (lines 12, 29-30), which might be public or may be religious officials in charge of the temple.

\section{Gytheion. Law/decree about a priesthood (polis) - first century BCE $(I G \mathrm{~V} 1,1144)$}

This decree contains an order to transfer the priesthood of Apollo to Philemon and Theoxenos, his son, and their descendants (lines 23-35) as a reward for their generosity in restoring the temple of Apollo (lines 1-22). There is an enactment formula (lines 22-23) and a publication formula (lines 35-38). This appears to be a one-off measure. The measure is called a nomos (line 36).

\section{Sparta. Calendar (polis?) - first century CE $(I G \vee 1,363)$}

There are names of gods (lines 1-2), a day of month (lines 6) and a month (line 17). Some scholars have restored the names of festivals. This appears to be a fragmentary calendar; line 9 mentions a law or custom that forbids something.

\section{Mistra. Law about sacred matters (uncertain) - Imperial period? $(I G \mathrm{~V} 1,364)$}

It is difficult hard to know who issued the rules. No officials are named. 


\section{Messenia. Law about sacred matters (polis) - before 191 BCE $(I G \mathrm{~V} 1,3447)$}

This seems to be a public regulation because there is a mention of public funds at line 17. There are dates (lines 5,7), and thus a form of calendar in the first part of the fragment. But lines 11-15 are concerned with sacred officials, specifically the thoinarmostria. There appears to be a clause in casuistic form (lines 13-15) and a monetary penalty (line 15).

\section{Andania. Law about sacred matters (polis) - 92/1 BCE or 24 AD (Syll. ${ }^{3}$ 736; for a convincing argument in favour of the later date, see $\boldsymbol{S E G ~ 5 9 : ~ 4 0 3 ) ~}$}

This is one of the most elaborate set of rules about a cult, which is established by the city. The rules are called a diagramma. This document names many officials - synedroi, sacred men, the Ten, the Five, epimeletes, archons, gerousia, gynaikonomos, auletes, herald, seer, agoranomos, nomodeiktes, agonothetes, hierothytai, argyroskopos, tamiai, dikastai, rhabdophoroi. There are sections about oaths to be sworn by officials (lines 1-11), the paradosis of sacred books (lines 11-13), wreaths to be worn (lines 13-15), clothes to be worn by initiates (lines 15-26), the oath of the gynaikonomoi (lines 26-28), the order of people in the procession (lines 28-24), tents (lines 34-39), the power to punish the disorderly with the help of the rhabdophophoroi (lines 39-45), dancers to be appointed (lines 73-75), prosecution of theft (lines 75-78), protection of wood in the sanctuary (lines 7880), supplication of slaves (lines 80-84), sacrifices at a fountain and the perquisites of Mnasistratus (lines 84-89), construction and supervision of treasuries (lines 89-95), a sacred meal (lines 95-99), buying and selling in the agora (lines 99-103), the powers of the agoranomos in policing water in the agora (lines 103-106), in policing the baths (lines 106-111), the duty of the sacred men to reports violations to the prytaneion (lines 111-113), the nomodeiktai in making available the diagramma (lines 113-115), the appointment and powers of the Ten (lines 116-179), and rules about matters not covered in the diagramma (lines 18094). There are many fines listed for offenses, and some legal procedures. For detailed recent treatments, see Deshours (2006); Gawlinski (2012). On legal aspects, see Harter-Uibopuu (2002). 


\section{Messenia. Law/decree about cult personnel (polis) - second century BCE $(I G \mathrm{~V} 1,1498)$}

The enactment formula of the measure is lost, but there is a publication clause (lines 12-14) instructing civic officials (biduioi) to place the measure in the temple of Demeter. The measure is called a nomos (line 8) and a rhetra (line 12, self-referentially in this second case). All of the regulation is concerned with the duties and obligations of the female cult official known as thoinarmostria ('banquet-setter'; cf. lines 4-5, 6, 7-8 and 11). The first two lines of the inscription appear to contain an order with a verb in the future, and concern a meal, but are very fragmentary. There follows a rule in casuistic form with a penalty of two hundred drachmas (lines 3-5). There is also a rule in casuistic form with a penalty of two hundred drachmas (lines 7-10).

\section{Tegea. Law/decree about sacred matters (polis) - fourth century BCE $(I G \vee 2,3)$}

The inscription lacks a prescript but contains the names of public officials (bieromnamon: line 3) and public bodies (lines 20-21: Thirty and Three Hundred) and concerns both citizens and foreigners (lines 11-12). If the bieromnamon does not fine offenders, he owes one hundred drachmas to the people and is cursed (lines 4-5). There is a term (inphorbien, inphorbismos) that appears to be a tax to be paid for pasturage (lines 2, 3-4, 7, 25; thus Sokolowski and Chandezon). The inscription was found in the city of Tegea and applies to land called Alea (lines $5,11,16)$, which may be public property used for the sanctuary of Athena Alea (Pausanias 8.45.4-5). For discussion see Chandezon (2003), p. 33-40.

\section{Lykosoura. Law about sacred matters (unclear) - third century $\mathrm{BCE}(I G \vee 2,514)$}

This is a series of rules about how to behave in the sanctuary of Despoina, first how to dress and wear one's hair (lines 2-13), then how to sacrifice (lines 1419). There is a rule in casuistic and prescriptive form calling for illegal items to be dedicated as a penalty; the authority cited is the stele itself (lines 7-9). Because Pausanias (8.37.8-9) indicates that these mysteries were conducted by all the Arcadians, this might be a law/decree of a polis even though there is no enactment formula or officials named; however, it could also simply be a regulation of the sanctuary itself. 


\section{Oropos. Law/decree about a priesthood (polis) - fourth century BCE (either 411-402 or 386-77) (Syll. $\left.{ }^{3} 1004\right)$}

This gives the duties of the priest at the sanctuary. There is a rule in casuistic form granting the priest the power to impose fines and to distrain the property of offenders (lines 9-16). For the meaning of enechyra and similar clauses in rules about penalties see Harris (2008), 82-83. The priest acts in accordance with the law (lines 9, 17, 39) and conducts trials (lines 17-20). He has the power to inflict summary fines up to three drachmas; all cases involving larger amounts must be decided by a trial (lines 13-17). The priest is to issue a summons and decide the case on the same day or the following day if the defendant requests a delay (lines 18-20). For similar rules about imposing fines see $I G \mathrm{i}^{3} 82$, lines 24-28; Agora 16: 56[3], lines 32-38. The rules mention citizens and foreigners (lines 1415), which indicates that this is a public cult, and the rules will probably have been issued by the polis of Oropos during one of its two periods of independence. For translation and brief commentary, see Rhodes and Osborne (2003) 128-134 (= GHI 27; but the translations of the legal provisions in lines 11 and 18-20 contain mistakes).

\section{Oropos. Decree with an order about melting down dedications (polis) - third century BCE (IG VII 303)}

This is a decree of the Boiotian confederacy (lines 1-2) with an enactment formula (lines 2-4, 11). It orders old dedications to be melted down to make phialai (line 30) and is similar to nos. 41 and 42. There follows a list of the new phialai dedications (side B). There is a rule penalizing officials in casuistic form (lines 48-52). This is a one-off set of orders, not a law about sacred matters.

\section{Oropos. Law/decree about sacred matters (polis) - third century BCE (IG VII 351)}

This is a decree of the people of Oropos, a member of the Boiotian confederacy (enactment formula at line 10; publication formula at lines 14-17). A decision is made instructing the archon, polemarch, and secretary to henceforth/regularly send a cow to the federal festival of the Ptoia (lines 1014). 


\section{Tanagra. Decree with an order to construct a temple of Demeter (polis) - end of the third or beginning of the second century BCE (Syll. $\left.{ }^{3} 1185\right)$}

This is a decree with an enactment formula (lines 1-3,10) taken in accordance with an oracle of Apollo (lines 7-8). The measure calls for a subscription to be raised by contributions from women (lines 19-20), whose names are listed at the end of the inscription (lines 44ff.). There is also an allusion to the law of the Boiotian Confederacy (lines 16-17). This is not a law because it does not create rules for the future. See Migeotte (1992), 75-81.

\section{Akraiphia. Law/decree about sacred matters (Panhel-lenic sanctuary) - 228-26 BCE (Syll. $635 \mathrm{~A}$ and B)}

This is a dogma of the Amphictyons at Delphi (lines A21-2, 24) granting asylia to the sanctuary of Apollo at Akraiphia. There are rules in casuistic form (lines A4-5, 21-24) with penalties imposed by the Amphictyons. They have these laws sent to the cities (lines A24-26). The measure in question is called a psephisma (lines A16-17) and copies are placed in different locations (lines A17-19). Side B refers to a consultation of the oracle of Trophonius, which authorized the dogma.

\section{Lebadeia. Law/decree about sacred matters (polis) - fourth century BCE (IG VII 3055)}

There is a prescript, indicating a law of the city (line 1). This concerns fees to pay for consultation of the oracle of Trophonius (lines 3-4, cf. Paus. 9.39.5). There seems to be penalties for violations (lines 5-7). A list of fees paid or consecrated then follows (lines 8ff.).

\section{Orchomenos. Law/decree with an order about sacred matters (polis) - third century BCE (Syll. ${ }^{3}$ 994)}

This is a decree of the city (enactment formula in line 6) about assuring a supply of water in the shrine of Zeus Meilichios, but there is no mention of a penalty or officials to enforce the rule. This is a one-off order for building a springhouse or well (line 9), not a law. 


\section{Delphi. Sign (polis or sanctuary?) - fifth century BCE (Choix Delphes 23)}

This appears to be a sign: it is placed on the wall of the stadium, contains no enactment formula, and mentions no officials. It forbids anyone to bring wine out of the stadium. In case of an infraction, it imposes both a fine and a propitiatory sacrifice.

\section{Delphi. By-laws (gentilicial association) - early fourth century BCE (Choix Delphes 30)}

This is a set of by-laws of a group called the Labyadai. The first part of the preserved document gives an oath of the tagoi (lines A1-18). This is followed by an enactment formula (lines 19-23). There are rules about sacrificial animals to be brought by the tagoi, and a fine of ten drachmas for not receiving them on the right day (lines A31-43), and rules about depositing sacrificial animals and cakes (lines A44-59). The Labyadai are to vote according to the laws of Delphi (lines B1-18). There are several fines for the tagoi (lines 30-34). Those who violate the rules about offerings and sacrifices can be fined or excluded from the group (lines B35-50). Column C starts with rules about trials. If someone is elected and does not decide the case, he is fined five drachmas and replaced (lines C3-9). Successful accusers are to have one half of the penalty (lines C1018). The tagoi are responsible and are fined double the amount if they do not perform their duty (lines C12-19). The rest of the column contains rules about funerals (lines C19-52). Column D contains different types of rules: a list of feasts (lines D3-29); a copy of the inscription at Panopeus/Phanoteus (lines D29-43); and finally another list of sacrifices (lines D47-51). The demiorgoi and other Labyadai are to impose fines, and the Fifteen to collect it (lines D17-22). Sokolowski provides a text of only Face $\mathrm{C}$ and Face D. For a complete text and translation see Rhodes and Osborne (2003) 2-7 (=GHI 1); for the newly published inscription at Panopeus/Phanoteus and a revisiting of the context of the dossier, see now Rousset, Camp and Minon (2015), 441-463.

\section{Athens. Law about sacred matters (Panhellenic sanctuary) - 380-79 BCE (IG II ${ }^{2}$ 1126; Choix Delphes 27)}

This is a law enacted by the Amphictyons of Delphi. The first part of the law gives the oath sworn by the bieromnemones (lines 3-9), then follows an oath sworn by the secretary (lines 10-13). There are rules about the inspection of 
land with penalties for those who cultivate sacred land and for those who do not conduct the inspection (lines 15-21), lodging for visitors (lines 21-26), washing(?) with penalties indicated (lines 26-34), repairs with penalties for the Amphictyons who do not carry out repairs (lines 35-40), the construction of bridges (lines 40-43; a penalty may be mentioned at line 43), and the sacred truce (lines 43-49). There is a penalty for not sending messengers to announce the truce (line 46). If a city does not accept the truce, they are to be excluded from the shrine (lines 47-48). For discussion see Harris (2015), 61-62.

\section{Delphi. Decree about sacred matters (Panhellenic sanctuary) - 178 BCE (Syll. ${ }^{3}$ 636: CID IV 108; Choix Delphes 157)}

This is a dogma (line 32) of the bieromnemones of Delphi and has an enactment formula (lines 1-19) and a publication formula (lines 31-32). It sets apart a portion of sacred land for sacred cows and horses (lies 19-25). It forbids privately owned animals from pasturing in this area (lines 25-28) and contains a rule in casuistic form allowing anyone to seize cattle violating the rule (lines 2831). For translation and discussion see Chandezon (2003), 55-56, 62-69 (discussion of sacred land).

\section{Delphi. Decree about a donation by Attalus II (polis) - 160/59 BCE (Syll. 672; Choix Delphes 168)}

Sokolowski prints only lines 44-63, which concern the sacrifices to be made, and omits the prescript showing that this a measure passed by the city of Delphi (lines 1-2, 12-13; cf. also its publication formula, lines 61-63). King Attalus has made two donations, one of 18,000 drachmas for the education of children (lines 6-8), the other for sacrifices (lines 44-63). There are extensive rules about the loans made on security from this fund (lines 21-31, 63-88). This perhaps qualifies as a law about sacred matters in the sense that there are rules about sacrifices, but they are contained in a general measure about Attalus' donation. For discussion see Harris, "Toward a Typology" (2015) and Migeotte (2009-2010).

\section{Delphi. Law/decree about a donation by a private citizen (polis) - 182 BCE (Syll. ${ }^{3}$ 631; Choix Delphes 137)}

The inscription contains rules about a donation made by Alkesippos of Calydon (line 2). The inscription gives an archon date (line 1) but does not contain an 
enactment formula. On the other hand, it does give the instructions made to the archons to inscribe the terms of the donation on the temple where it was found (lines 8-10). The inscription gives the amount of the donation (lines 2-3), the sacrifice and damothoinia to Apollo to be called the Alkesippeia (lines 4-6) and the procession led by the priests of Apollo, the archon, and the prytaneis (line 68). The instructions appear to have come from the donor's will (the phrase in lines 3-4 being equivalent to "in the event of my death"). Strictly speaking, the inscription is not the publication of a decree about sacred matters (which must have been recorded elsewhere, possibly in the city's archive), but the publication of the terms of a will, which have been accepted by the city. It is therefore unlike the preceding inscription even though both concern donations to the city. For discussion see Harris, "Toward a Typology" (2015), 72-74.

\section{Elateia. Sign (unclear) - end of the fifth century BCE (IG IX 1, 129)}

This contains two orders, one allowing banqueting and lodging after sacrifice (thus Ziehen; cp. e.g. SEG 57: 1674, lines 7-8), the other forbidding women to enter. There is no indication of the authority, officials or a penalty.

\section{Korope. Law/decree about sacred matters (polis) - around 100 BCE (Syll. ${ }^{3}$ 1157)}

This is a measure of the city (line 67: psephisma) with a list of proposers including officials (lines 1-8) and an enactment formula (line 17-18). There are several rules for keeping order at the oracle and about consulting the oracle (lines 18-28) and penalties for officials who do not carry out their duties (lines 28-30) or swear the oath at a meeting of the Assembly (lines 59-61) in casuistic form. The generals and nomophylakes are to appoint rbabdouchoi to punish the disorderly (lines 23-26); these officials are to be given a drachma a day for food (26-28) and are to be fined three drachmas for not reporting for duty (lines 2830). There is a penalty in casuistic form for the exestastai who do not carry out their duties (lines 61-63). There is a publication formula (66-69).

\section{Korope. Law/decree about sacred matters (polis) - around 100 BCE (Syll. ${ }^{3}$ 1157)}

On the same stele as the preceding inscription. The measure contains a long prescript (lines 1-4) and an enactment formula (lines 8-9, 24-25). There are rules 
forbidding the cutting of trees (lines 9-13) and grazing (lines 13-14). There is a fine of fifty drachmas (restored) with half going to the person who reports the infraction and fifty lashes for slaves and a fine of one obol per animal (lines 1418). Charges are to be made to the officials indicated (lines 18-19). There is a publication formula (lines 19-24).

\section{Magnesia. Law/decree about sacred matters (polis) - around $100 \mathrm{BCE}$}

The measure mentions the assembly (lines 5, 9, 13) and concerns the sale of hides from the cult of Zeus Akraios (lines 3-11). There may be a penalty in casuistic form (line 11-12).

\section{Ithaca. Copy of a dedication of land and sign (private) - second century $\mathrm{CE}$}

The text is identical with that found in Xenophon Anabasis 5.3.13, about the author's dedication of land to Artemis at Skillous. The small copy was probably made to be included in a collection of a local notable or a Roman. As a regulation (i.e. in the original context intended by Xenophon), it binds whoever possesses the land to sacrifice a dekate every year to Artemis and threatens those who do not with the wrath of the goddess.

\section{Tomis. Contract for priestly personnel (polis?) - third century BCE (IScM II 1)}

This measure indicates the duties (expressed in verbs in the future indicative) of the person who purchases the priesthood of the gods of Samothrace and the reward of a crown for the priest (lines 1-15). The measure is then followed by a statement that Timaeos, the son of Strato, has purchased the priesthood for eight gold staters and sixty bronze (lines 15-17). These duties are complemented by reference to a nomos (line 13), perhaps another document relating to the cult. There is a fragmentary document on another column inscribed on the stele (not included by Sokolowski), which may be an honorary decree for Diagoras, possibly the founder of the cult; there is a mention of the demos in this context. 


\section{Olbia. List of officials and sign - third century BCE (Syll. ${ }^{3}$ 1039; IosPE $\mathrm{I}^{2}$ 75)}

This is a list of people who held the office of the Seven and administered a treasury (probably that of their board, lines 1-10). The officials appended a small sign or regulation concerning the proper sacrificial tariffs to be paid by those offerings sacrifices (lines 11-15); however, the prices for each sort of animal appear to be very large.

\section{Phanagoria. Law/decree (?) about sacred matters (unclear) - second century $\mathrm{CE}$}

The measure contains rules about the mysteries of a goddess, but is very fragmentary. There may be sanctuary officials mentioned (lines 20-21). It is impossible to tell which authority issued the rules.

\section{Callatis. Law/decree about sacred matters (unclear) - second century BCE}

Sokolowski thought that this was a calendar, but there is only one date given

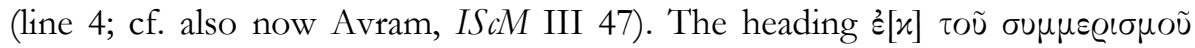
(line 1) remains unusual and difficult to interpret: it may suggest a subject (sacrificial division) or an excerpt from a larger document. There are rules about initiation into a cult of Dionysus, but no officials named. It is impossible to tell which authority issued the rules.

\section{Tamynai. Law/decree about sacred matters (polis) - fourth century BCE}

The first few lines are not preserved, but there are public officials mentioned in the fragment (lines 2-3 [demarch]; line 7 [bieropoioi]). The demarch is to administer the oath and is to pay a fine of 500 drachmas if he does not, or does not collect payment from those who do not swear the oath (lines 2-6). The bieropoioi are to collect this fine; if they do not, they will owe double the amount (lines 6-9). The rules appear to pertain to a woodland area around a sanctuary, since grazing is forbidden (lines 9-12). 


\section{Eretria. Decree about sacred matters (polis) - fourth century BCE (IG XII 9, 189)}

This is a decree of the Assembly (enactment formula in line 2). It covers games, sacrifices and processions at the Artemisia. There are amounts for prizes awarded to competitors and a subsistence allowance for all competitors (lines 15-24). There are officials responsible for running the games (demarchs in lines 24-6, line 35), who have the power to impose fines "according to the law" (lines 24-26). There is an exemption from taxes for those selling in the shrine (lines 32-35). There is a publication formula, identifying the measure as a psephisma (lines 41-43).

\section{Eretria. Decree about sacred matters (polis) - fourth or third century BCE (IG XII 9, 194)}

The prescript has not been preserved, but the measure is called a psephisma (line 33; publication formula at lines 33-35). There are public officials (lines 10, 29), and a clause in casuistic form about penalties for these magistrates if they do not perform their duties (lines 29-30). The poletai give money for the stele (lines $35-6)$.

\section{Delos. Sign (sanctuary or private association?) - second century BCE (IG XI 4, 1300)}

This is a sign found in the Serapeion with brief orders forbidding anyone to enter after drinking or in flowery clothes. There is no indication of authority, officials, penalties, but it was probably set up by those in charge of the Serapeion.

\section{Delos. Dedication and sign (private association?) - after 166 BCE (ID 2367)}

The inscription is very fragmentary. It begins with a dedication, containing names of persons and the name of a goddess (Artemis) in the dative (line 4). Appended to this, there appears to be a prohibition against entering after sexual relations or after eating fish (lines 5-6). 


\section{Mykonos. Decree about sacred matters, containing calendar (polis) - ca. 220-200 BCE (Syll. 1024)}

The inscription first has the form of a decree with an enactment formula (line 3-5), but then takes the form of a calendar with dates and sacrifices (lines 5-40). The law appears to integrate different sacrifices after the synoikism of the island (lines 2-3). Several groups of officials are mentioned: the council (lines 10, 13), archontes (lines 13, 19), bieropoioi (lines 17-18, 28), and a priest (lines 32, 34). For an analysis, see Reger (2001).

\section{Keos. Funerary law (polis) - fifth century BCE (IG XII 5, 593)}

This is called "laws about the dead" (line A1) and contains rules about burial but lacks penalties and officials. Side B contains further decrees inscribed on the stele, which is clear from the enactment formulas (cf. lines B1-3 in Sokolowksi).

\section{Keos. Law/decree about sacred matters (polis) - third century BCE (IG XII 5, 647)}

Even though the prescript is missing, this appears to be a law (line 1 [nomon]; line 41 [nomos]) of the city about a public festival - it refers to public officials: probouloi (lines 6, 14, 20, 27, 37), treasurer (lines 18-19), generals (line 19) and gymnasiarch (line 21). Citizens, metics and freedmen can participate (lines 911). The gymnasiarch has the power to impose fines of up to a drachma (lines 25-6). The rules also refer to those whom the polis has summoned, along with metics and freedmen (lines 9-10).

\section{Keos. Impossible to determine - third century BCE (IG XII 5, 646)}

This is very fragmentary. It appears to contain rules about purity. No officials or penalties are mentioned.

\section{Arkesine. Law/decree or sign about sacred matters (polis) - fifth century BCE $(I G$ XII 7, 1)}

This is very brief but contains a prescript indicating it is a decree, with the name of the proposer (lines 1-2). The substance is a prohibition against burning a fire 
in the sanctuary (lines 2-5) and a fine for violators in casuistic form (lines 4-6), but no mention is made of the officials who impose the fine. The brevity of the inscription may indicate that it is a sign containing an extract from a longer law.

\section{Arkesine. Law/decree or sign about sacred matters (polis) - third century BCE $($ IG XII 7, 2)}

This is found on the same stone as the previous law and has a prescript indicating it is a decree (line 2) and contains rules prohibiting foreigners from camping in the temple (lines 3-4). The neokoros is responsible for enforcing this rule and is subject to a fine of ten drachmas for each day he does not perform his duty (5-7). The neopoiai are to post the rule "before the doors" (lines 7-9). The brevity of the inscription may indicate that it is a sign containing an extract from a longer law.

\section{Arkesine. Law/decree about sacred matters or containing an order (polis) - fourth century BCE $(I G \mathrm{XII} 7,4)$}

This contains a prescript and is a decree (lines 1-2), but it is unclear if this is a general law or just a response to the report of an impiety about women in the sanctuary of Demeter (line 10) because the bottom part of the inscription is not preserved.

\section{Amorgos. Minoa. Law/decree about a donation to a festival (polis) - first century BCE $(I G$ XII 7, 237)}

This is a law of Amorgos made in response to a donation for the festival of the Metroa made by a woman named Hegesarete (lines A7-9), who is honored with the award of a crown and a public announcement (lines B25-31). An enactment formula is reasonably restored (line A8), and there are rules that apply to meetings of the Assembly (lines B18-25; 36) and public elections (B52-6). There are several public officials mentioned (prytaneis in lines B18; public herald in lines B 23, 27; agonothetai in lines B32; exetastai lines 60; and annual epimenioiappointed specifically to administer the donation, in lines A17, B20, 25, 38, 45 58). This is a composite document. Part A appears to start with a prescript and mentions officials elected by the people (lines 3-4). There are lengthy provisions about lending the donor's money to produce interest (lines A7-8, B4-5, 16-7, 33-52). Part B contains financial measures about lending. 


\section{Ios. Law/decree of uncertain character (polis?) - fourth century BCE $(I G$ XII 5,1$)$}

This is a fragment of an inscription and appears to contain a rule about pasturing cattle and contains a penalty but does not name an official. Sokolowski thinks this is a sacred law on the assumption that the measure concerns the grazing of animals on sacred land. This remains to be confirmed, though the document does bear some similarity to nos. 67, 91 (above), and nos. 105 and 136 (below).

\section{Ios - Law/decree concerning sacred matters (polis) - fourth century BCE $(I G$ XII 5,2$)$}

This is fragmentary, and the prescript is missing, but the measure names what appear to be public officials and fines are paid to the public treasury (lines 5-6). There is an oath required about pasturing and penalties for those who do not swear the oath (lines 5-6). A volunteer can denounce a transgressor to the bieropoioi and receive half of the penalty (lines 6-7).

\section{Ios - Law/decree about sacred matters (polis) - third century BCE $(I G$ XII 5, 1008)}

The inscription is very fragmentary, but there appears to be an enactment formula involving archontes (line 1). There are sacrifices for King Antigonos (either Gonatas or Doson, lines 1-2), and officials are named (line 2).

\section{Ios. Law/decree about sacred matters (polis) - second century BCE (IG XII 5, 1012)}

This appears to be the final lines of a law and contains the penalties. The text refers to a law (line 3), but it is difficult to tell whether the phrases refer to rules contained in another document or in the missing lines of this document. Sokolowski thinks that the inscription forbids a priestess from receiving too much money from those coming to a sanctuary, but it also appears to impose public penalties on private citizens (lines 3-4). 


\section{Paros. Sign (unclear) - fifth century BCE (IG XII 5, 107)}

This appears to be a sign. There is a rule about throwing rubbish above a road with a penalty of fifty-one drachmas (lines 1-10), but it allows volunteers to impose the fine (lines 10-12). Sokolowski believes that it comes from a sanctuary, but this is not clear. There was an altar to Zeus Hypatos on the acropolis, which was part of a public sanctuary (Pausanias 1.26.5).

\section{Paros. Boundary-maker with sign (unclear) - fifth century BCE (IG XII 5, 183)}

This is a boundary marker, obviously placed at the edge of a shrine of Zeus Hypatos, with a rule prohibiting those uninitiated and women from entering the shrine.

\section{Paros. Sign (unclear) - fifth century BCE (IG XII 5, 225)}

This is another sign forbidding Dorian foreigners to enter the shrine of Demeter and Kore.

\section{Paros. Law/decree about sacred matters (polis) - fifth century BCE (IG XII 5, 108)}

This appears to be the end of a document that contained rules about cutting wood in a sanctuary. There is a penalty for violators (lines 4-6) and rewards for the person who gives information (phasis) to the theoros (lines 4-6). The theoroi, magistrates of the city, are to take an oath of denial from the neokoros that he knows of no one cutting wood (lines 6-10). On the theoroi as public officials of Paros, see Rutherford (2013), 128, 136-138.

\section{Paros. Sign (unclear) - second century BCE $(I G$ XII 5,126$)$}

This appears to contain the final lines of a rule forbidding the use of fire in a sanctuary (cf. no. 100, above; $I G \mathrm{I}^{3}$, line B6). There is no indication of the authority that issues the measure, but a neokoros imposes the fine; it is uncertain if he was a public or sanctuary official. 


\section{Thasos. Sign (private association) - middle of the fifth century BCE}

This appears to be a sign inscribed on a wall. The deity mentioned (Athena Patroia) was linked to a family or private group and the inscription comes from the Thesmophorion of Thasos, where several other such texts have been found: cf. Rolley (1965) and Parker (2008). Women are allowed to participate in the ceremony.

\section{Thasos. Signs (polis?) - fifth century BCE (IG XII 8, 358)}

These are two signs placed below relief panels of an altar. They may be from a public shrine to the Nymphs, Apollo Nymphagetes (line A1) and the Graces (Line B1). The signs forbid certain sacrifices and the singing of a paean.

\section{Thasos. Law/decree about sacred matters (polis) - fourth century BCE (IG XII Suppl. p. 152)}

This is a decree or law (prescript in line 1) concerning the leasing of a garden of Heracles (lines 2-3). The lessee is bound to keep the area clean (lines 2-4) and has the right to punish free persons and slaves who throw in rubbish (lines 4-6). It is unclear what the term angos means in line 5. Public officials, the agoranomos and the priest of Asclepius, are made responsible to keep the area clean (lines 68) and are fined if they do not discipline the lessees (line 10). These are public officials for a public cult.

\section{Chios. Law/decree about sacred matters (polis) - fourth century BCE (Syll.3 986)}

This has an enactment formula and is a rule (gnome) of the Council (lines 1-2) against pasturing and leaving dung in the grove around a sanctuary (lines 2-5). Those who see violators are to report them to the basileis (lines 5-9). The penalty is one-twelfth of a stater for each animal grazing (lines 9-14), five staters for leaving dung (lines 14-17). Anyone who knows about this and does not report is liable to a fine of five staters (lines 17-20). There is a prohibition on taking items from the sanctuary and a penalty of an aresterion (a propitiatory sacrifice) for violators. Those who know about violators and do not report are liable to a fine of five staters (lines 25-30). Even though this contains an enactment formula and names officials (lines 8,26-7), it does not name the god 
to whom the shrine belongs (lines 9, 12) or its location. The inscription was posted at a shrine and the cult in question is thus left implicit in the text.

\section{Chios. Impossible to determine - fifth century BCE}

Sokolowski believes this regulation concerns the rights of priests; if this is right, the small fragment may have come from a contract.

\section{Chios. By-laws (phratry) - around 335 BCE (Syll. $\left.{ }^{3} 987\right)$}

The inscription contains three by-laws of the phratry of the Klytidai with two enactment formulas preserved and dates (lines 10-11, 22-24). The phratry uses the same word for its decision as the Council of Chios (line 36: gnome; compare no. 116, line 2-above). Two decisions were taken after favorable omens at a sacrifice (kallieresen: lines 6-7, 20-21) and an oracle (lines 15, 39). The first decision was to build a common shrine and bring sacred items there (lines 6-10). The second decision reports the decision to bring all sacred items to this common shrine (lines 10-22). The third lays down penalties for those using the common shrine for private purposes in casuistic form with a penalty of 1,000 drachmas for Zeus Patroos and a curse (lines 31-36). The by-law refers to laws about curses of the phratry (line 36) and concludes with a publication formula (lines 36-41). Sokolowski thinks that the by-laws result from a "democratization", but it is not clear why this should be so. The building of a common shrine has simply led to a decision to place sacred items in it and to lay down rules about their use, suggesting instead a degree of "centralization" or "formalization" of the group.

\section{Chios. Contract for priestly personnel (genos) - fourth century BCE (Syll. $\left.{ }^{3} 1013\right)$}

There is no enactment formula, but the rules pertain to a genos (line 2) and concern the perquisites for its priest of Heracles (lines 1-9). If the priest is not present, a member may call out and sacrifice, but must give a portion to the priest (lines 9-14). There are no penalties mentioned for violations. It is clear that the document presumes a sale of the priesthood, much like other priesthoods connected to the genos were apparently sold (cf. lines 14-17). 


\section{Chios. Contract for priestly personnel (polis) - fourth century BCE}

This concerns the perquisites of a priestess. Though fragmentary, the preserved parts of the inscription indicate that the cult in question was public (reference to a public sacrifice in line 10; grant of tax exemption in lines 10-12).

121. Chios. Boundary-stone with a sign (unclear) - the date is not indicated by Sokolowski; probably fourth century BCE on the basis of letters and dialect forms

This is a sign on a boundary-stone. There is only a prohibition about entry with no indication of penalty, officials, or authority.

\section{Samos. Law/decree about sacred matters (polis) concerning subdivisions of the polis - third century BCE (Syll. $\left.{ }^{3} 1043\right)$}

The rules are introduced by the nomographoi (line 1). There is a rule that the epimenioi elected by the chilisteres are to supervise sacrifice and the meeting in the Helikonion; they are to elect substitutes if they are absent (lines 2-5). There is a rule about self-nomination, probably (according to the restoration) to the office of epimenios as a form of liturgy (lines 5-6). There is a penalty for failure to perform this duty imposed by the nomophylakes (?) and the epimenioi in casuistic form (line 6-8).

\section{Samos. Decree of Assembly concerning priesthood (polis) - second century BCE (Syl1. ${ }^{3}$ 666)}

This is a decree of the Council and Assembly (enactment formula in lines 1-4), but is a response to a formal supplication about collecting money (ageirein) by a priest of Isis who has placed a suppliant's bough in the Council (probably at the altar, lines 5-7). On the suppliant's bough, see Naiden (2006), 56-57. The Council must have submitted his request to the Assembly, which determined that it was legitimate (line 8). This document is an order, similar to no. 34, but concerning the collection performed by the priest. Dunand (1973), 61-62, discusses the inscription and the practice of agermos, but does not discuss the reasons for the supplication and the status of the cult in this period. There are questions about the status of the cult of Isis: is this a private or a public cult? And the status of the priest: is he a citizen or a foreigner? At Athens, foreigners 
could use the procedure of supplication to approach the Assembly ([Arist.] Ath. Pol. 43.6; IG II 218 [Dioscorides of Abdera]; 336 [Olynthians?]; 502 [Antiphates, a public slave]). It is thus possible that the priest is a foreigner who approaches the Assembly by supplication and perhaps makes a request about a private cult of Isis, though collections are also well attested in public cults (cf. e.g. $L S A M 73$, Halikarnassos).

\section{Eresos. Law about sacred matters (unclear) - second century BCE (IG XII Suppl. p. 38, no. 126)}

This is a list of rules about purity for those entering a sanctuary, which also had a temple (naus, line 15). There is no prescript preserved, and we therefore cannot know for certain which authority issued the rules. No civic officials are named, and no penalty is mentioned. One possible clue for the context of the document is the mention of a priestess and prophetess (lines 19-20), suggesting that the sanctuary may have controlled its own rules. Women are excluded from the temple (but not the sanctuary itself); also barred are worshippers of Kybele: galloi and women who gallazen (lines 11-12).

\section{Mytilene. Sign (unclear) - second century BCE (IG XII 2, 72)}

These are sacrificial tariffs, indicating what must be deposited in the thesauros in different ritual cases. But no prescript is preserved, no officials are mentioned and no penalty is indicated.

\section{Mytilene. Sign (unclear) - second century BCE (IG XII 2, 73)}

The inscription contains rules about sacrifices on the altar of Aphrodite, Peitho and Hermes and forbids sacrifice of pork and birds. Apart from a standard invocation (line 1), the prescript has no indication of the authority: there are no officials mentioned, and no penalties. This appears to fall into the category of signs.

\section{Methymna. Law/decree about sacred matters (polis?) - fourth century BCE (IG XII 2, 499)}

The opening lines have not been preserved. The mention of thyrsoi suggested to Sokolowski a cult of Dionysus (line 13), and Sokolowski restores mysteria in line 
13. Sokolowski thinks it concerns Dionysiac mysteries for women. As preserved, the rule appears to order the official gynaikonomos (line 5) to stand outside the doors and ensure that no man enters the temple and that no impiety is committed (lines 7-10; cp. also line 3, possibly other officials mentioned with the participle diakoneontes). If this gynaikonomos is an official of the polis or one of its subdivisions, this is a law/decree (cp. $L S A M 16$ for the civic gynaikonomos). There is no mention of a penalty; the rules mention a proclamation (kerugma, line 4).

\section{Dardanos or Mytilene. Calendar (private association) - Imperial period (IG XII Suppl. p. 16, no. 29)}

This is a calendar with the names of months (lines $2,4,5,6$ ). The document was written by Aristippos on the order of the god (the method of consultation or inspiration is not fully specified). The fact that Aristippos uses the first person singular and has no official title suggests that this inscription is for a private cult.

\section{Anaphe. Decree of Council and Assembly with order about sacred matters (polis) - second century BCE (IG XII 3, 248)}

This is a decree of the Council and Assembly (lines 4-5, 33-36), but derives from the authority of an oracle (lines 2-3, lines 21-33). Timotheus the son of Sosikles, has made a request that land be given in the shrine of Apollo Asgelatas to build a temple of Aphrodite (lines 6-20). Timotheus has asked the god about his request and received a favorable reply (lines 20-33). The oracle has specified that the temple belong to the polis (lines 20-21). This is not a law, but a decision (line 4: gnome; line 32: psaphisma) issued in response to an oracle, and therefore an ad hoc order that contains no general rules.

\section{Astypalaia. Sign (unclear) - third century BCE (Syll. $\left.{ }^{3} 980\right)$}

There is an order forbidding entry to the shrine for those who are not pure (lines 1-2). There is no mention of officials, penalties, or the divinity to whom the shrine belongs. This is a sign. 


\section{Thera. Sign (unclear) - fourth century BCE (IG XII 3, Suppl. no. 1369)}

There are only two words: "of Kore" and an offering: "pelanos". This is a sign and was inscribed on an altar.

\section{Astypalaia. Sign (tribe) - third century BCE (Syll. $\left.{ }^{3} 980\right)$}

This is connected to a tribe of the city (Hylleis) and prohibits the taking away of sacrificial meat (line 3). No official or penalty is named. This is a sign.

\section{Thera. Sign (unclear) - around $400 \mathrm{BCE}(I G \mathrm{XII} 3,452)$}

This is a sign, perhaps for a group (see the problematic line 1 and the plural form in line 2), with two dates, one for a sacrifice, the other for a meal. It is inscribed on a rock at the entry to a cave where the worshippers probably met, and it mentions a sign (line 5), perhaps the text itself or a symbol that was located nearby.

\section{Thera. Boundary stone (unclear) and sign (private) - around $400 \mathrm{BCE}$ and shortly afterward (IG XII 3, 452)}

This document was originally one of a set of boundary-markers for the land of the Mother of the Gods (lines 1-2). A certain Archinos later added another inscription (in a different hand) concerning his sacrifice. Sokolowski thinks that he has dedicated the land in question and requires lessees to sacrifice first-fruits twice a year (lines 6-18). This is possible, though the sanctuary seems to have existed earlier. It may also be that Archinos has simply made a commemoration of his own sacrifice and enjoined worshippers to follow his example, beginning "on the first year" (lines 6-8). In any case, this second appears to be a sign inscribed privately. No officials or penalties are mentioned.

135. Thera. Will with donation (private) and by-laws (private association) - third century BCE (IG XII 3, 330)

This document has been called the "will of Epikteta" (the title of Wittenburg [1990]) but only the first part contains the provisions of her will, lines 1-108; for the term diatheke see line 45). The second and longer part contains the bylaws of a private association, to which Epikteta donates money in her will (lines 
109-287). Just as the city of Delphi accepted the donation and terms of the will of Alkesippos (see above, no. 81), this group (koinon tou andreiou ton syngenon or simply andreios ton syngenon) also votes to accept the donation of Epikteta (lines 126-7). The by-laws (referred to as nomos or nomoi, e.g. lines 145, 164, 176, 207 , $213,227,239-247$, etc.) of the association provide rules about annual meetings (lines 131-38), about cultic officials (epimenioi) with penalties for those who do not serve (lines 138-46), about the duty to lend out the association's funds for interest and on real security (lines 146-54), the appointment of epimenioi when no one volunteers (lines 155-67). There are detailed rules about the duties of various officials with several penalties for officials in casuistic form (lines 167256). There is also an entrenchment clause to protect the group's existence, which renders null and void any proposal to dissolve the group and lays down penalties in such a circumstance (lines 256-67). The by-laws end with a long provision about record-keeping (lines 267-88). For detailed discussion and translations into Italian, French, English and German, see Wittenburg (1990); cf. also Carbon and Pirenne-Delforge (2013), 71-73 etc.

\section{Ialysos. Decree containing a law about sacred matters (polis) - around 300 BCE (IG XII 1, 677)}

Lines 1-2 contain a prescript with an enactment formula. The decree (lines 118) validates and publishes a law about rules for entry to the sanctuary of Alektrona (lines 19-35). For detailed discussion, see Chaniotis (2009), 91-105, and Harris (2015), 65-66.

\section{Lindos. Law/decree about sacred matters (polis) - $23 \mathrm{AD}$ (IG XII 1, 762)}

There is an enactment formula (lines A1-5, 12), and the measure is called a gnome of the epistatai. Six foreigners are to be chosen as choregoi in addition to the citizen choregoi (lines A15-20) to supervise a procession for Dionysus (lines A7, 20-21) at the Sminthia. Side B is very fragmentary but appears to be a continuation of the decree. The rules are presented as supplementary to traditional practice (lines 13-15), but in imperatival form. This is thus not an order, but rather new rules that form a part of the civic legislation concerning the festival. 


\section{Rhodes. Decree with an order to inscribe a list of priests (polis) - late second or early first century BCE (Syl1. $\left.{ }^{3} 723\right)$}

This is an excerpt of a decree (ek tou psephismatos, lines 1-2) about writing up a list of the names of priests. This is a one-off order: it is about maintaining public records, not prescribing rituals. Priests are instructed to write down names, but there are no penalties mentioned. The list of priests is not included in Sokolowski.

\section{Lindos. Law about sacred matters (unclear) - second century CE (Syll. ${ }^{3}$ 983)}

This is a list of rules about entering a sanctuary, requiring pure hands and pure thoughts (lines 2-8). Rules specify the length of time before entering the sanctuary after certain activities (lines 9-18). There is no mention of officials, authority, or penalties.

\section{Lindos. Sign (polis?) - third century BCE (Syll. $\left.{ }^{3} 1030\right)$}

This appears to be a sign and calls for the sacrifice of a pig to Poseidon on a certain date. There is no mention of officials, authority, or penalties, but it isno doubt correctly-thought to be a small excerpt from the civic sacrificial calendar (see Sokolowski, Segre 1951).

\section{Lindos. Sign (polis?) - third century BCE (Syll. $\left.{ }^{3} 1031\right)$}

This appears to be a sign and calls for the sacrifice to Dionysus on a certain day. There is no mention of officials, authority, or penalties, but it is - no doubt correctly-thought to be a small excerpt from the civic sacrificial calendar (see Sokolowski, Segre 1951).

\section{Lindos. Sign (polis or private group?) - third century BCE (IG XII 1, 892)}

This is another sign. Sokolowski rightly places this among "règlements publics et privés affichés devant les autels ou endroits où se pratiquait le culte.” There is no mention of officials, authority, or penalties. It is-perhaps correctlythought to be a small excerpt from the civic sacrificial calendar (see Segre 
1951), though in this case the rites belong to a subcivic group of uncertain character, the Lakoi.

\section{Rhodian Peraea. Physkos. Decree with an order (?) concer- ning sacred matters (polis) - around $100 \mathrm{BCE}$}

There is a prescript in which an enactment formula has been plausibly restored (lines 1-5). The inscription is very fragmentary but appears to concern the purchase of sacrificial animals (lines 6-8) at Lindos and in its deme of Physkos.

\section{Lebena. Laws/decrees about the paradosis of sacred treasures (polis) - second century BCE (I. Cr. I 2)}

The two inscriptions are fragmentary but appear to contain similar rules of the polis (brief prescript in line A1) about the paradosis (lines A2, A4, A10, B3, B4, B7) of items in a sanctuary (Sokolowski thinks of Apollo). An official called the naokoros appears to be responsible (lines A7, B5). The measure is called a psarimma (line B7, the equivalent of psephisma) and is enforced by public officials. The iarorgos has the right to impose fines (line A5: epitimon and line B4) and is subject to a penalty if he does not (line A6). On the paradosis, see Fröhlich (2011).

\section{Axos. Law/decree about sacred matters (polis) - end of fourth century BCE}

The inscription is fragmentary, but there are several public officials mentioned and, for instance, a penalty clause requiring a sacrifice of 100 cows for infractions (lines 13-16). This is almost certainly a copy of an Archaic or Classical law of the polis concerning rites and other matters involved in the cult of Apollo Pythios.

\section{Gortyn. Calendar (polis?) - beginning of fifth century BCE (IC IV 3)}

This inscription is very fragmentary but appears to be a calendar naming at least one month and date (line 1), sacrificial animals and divinities. There is no indication of the issuing authority, but the city is a good candidate. 


\section{Gortyn. Law/decree (?) concerning sacred matters (polis?) - fifth century BCE}

This inscription is very fragmentary. Sokolowski believes that it may pertain to a public cult. The mention of perioikoi (line 10) may indeed point to a civic context.

\section{Gortyn. Law concerning sacred matters (sanctuary or private?) - third century BCE (IC IV 186)}

This fragment contains the last lines of a series of rules protecting a sacred grove, with a penalty clause at the end granting the power to anyone happening to be present to hinder or obstruct the removal of wood "according to the ancient law (or rule)". It is difficult to identify the authority, but the absence of a more specific penalty may point to a non-civic context.

\section{Cyprus. Law/decree concerning sacred matters (polis?) - third century BCE}

There appear to be two penalty clauses about sacred boundary stones, one for free persons imposing a payment (lines 1-4) and one for slaves including lashes and sale in the marketplace (lines 5-7), with the proceeds of the sale going, perhaps, to a goddess (lines 8-9). If the restoration of the name of officials is correct (line 6), this is a law/decree of the polis.

150. Cos. Law/decree about sacred matters (polis) - second half of fourth century BCE (text A); ca. 300 BCE (text B, on a separate stele) (IG XII 4, 283-284)

Text A does not contain an enactment formula, but has a penalty for cutting or removing cypress-wood from a sanctuary (lines A1-6). The assembly decides if the offense qualifies as asebeia (lines A5-7). Anyone can denounce an offense to the epimeletes of the sanctuary or the assembly (lines A7-11). Side B names a proposer (line 1), has a motivation clause (lines B1-8) and contains an entrenchment clause (lines B8-12). The final part of side B is very fragmentary but mentions the assembly (lines B14 and 16). 


\section{Cos. Calendar (polis) - mid-fourth century BCE (Syll. ${ }^{3} 1025-$ 1027; IG XII 4, 275-278)}

These are four stelai (A-D) from the civic sacrificial calendar, containing elaborate prescriptions (cf. line A25 for the civic context). As in most calendars, no penalties are mentioned. For a detailed treatment, see Paul (2013), 375-382 and passim.

\section{Cos. Sign (polis) - ca. 300 BCE (IG XII 4, 285)}

The inscription begins with a proposer, but he is not given a title, and there is no enactment formula; nevertheless, it may derive or be abbreviated from a decree. There is a rule that all sacrifices to the Nymphs in the Asklepieion should be made at altars and no offerings thrown down the springs (lines 1-7). There is a clause in casuistic form about violations, and the offender is ordered to clean the shrine (lines 7-9). This is a sign about a public shrine.

\section{Cos. Calendar (polis or other group?) - second half of second century BCE (IG XII 4, 282)}

This fragment appears to be from a calendar: there are divinities (lines 1-2,6) and days of the month (line 5). The issuing authority cannot be determined.

\section{Cos. Law/decree about sacred matters (polis) - ca. 240 BCE (IG XII 4, 72)}

This starts with an elaborate dating formula (lines A1-3), a proposal by the exegetai (lines A4-5), two enactment formulas (lines A6-7, 19) and several publication formulas about stelai to be erected at the shrine of Demeter (line A11), the Asklepieion (line A12), the shrines of Artemis Toxitis and Lochia (lines A16-17), and the Aphroditeion (line A17). Leukomata (?) are to be placed in the demes of Isthmos and Halasarna (lines A17-18) and at a place where doctors congregate (lines A18-19). The text primarily contains purification rules, some concerning the priestess of Demeter Olympia (lines A21-35), others, that of Demeter at Isthmos (A 36-46). Another part (B) contains more general rules about purification, but there are no penalties mentioned in the preserved sections. Officials of the polis are occasionally mentioned (cf. line B27). 


\section{Cos. Law/decree about sacred matters (polis) - 242 BCE or shortly prior (IG XII 4, 71)}

This is a measure enacted by the assembly (lines A1-2) to set up a treasury in the temple of Asclepius (lines A2-3). This part is a specific order: the poletai are to contract the work, and the priest, prostatai and bierophylakes to indicate the place (lines A3-6). The treasurers are to give the money and to record expenses (lines A6-15). Provisions are made about keys (lines A15-17). There are also more general rules: the treasurers are to provide funds for festivals and rituals (lines A18-23). Face B, very fragmentary, appears to contain more financial regulations.

\section{Cos. Law/decree about sacred matters (polis) - first half of the third century BCE (IG XII 4, 332a+b)}

No prescript is preserved. The inscription is heavily restored but appears to concern the duties of civic priests; the polis is mentioned several times (lines A21, 26, 32). There is an entrenchment clause (lines B22-29) and two penalties for failure to observe rules about purity with fines and removal from office (lines B 29-35). These are rules about public cults.

\section{Cos. See no. 156 above - first half of the third century BCE (IG XII 4, 332c)}

As restored in $I G$, this fragment properly belongs to the same set of laws as the previous inscription (thus confirming Sokolowski's comment but not his numbering).

\section{Cos. Fragment of law/decree about sacred matters (?) (polis) - mid-third century BCE $(I G$ XII 4, 288)}

Sokolowski (following Herzog) believes that this contains rules about the asylia of the Asklepieion, but this is based on adventurous restorations. There are mentions of legal proceedings (lines 2 and 8 ) and laws (line 6). The polis may be mentioned in line 9. 


\section{Cos. Law/decree about sacred matters (polis) - mid-third century BCE $(I G$ XII 4, 286)}

The prescript is not preserved, but there are orders for the treasurers to provide funds for sacrifices (lines 4-6). The polis is mentioned in line 12, along with several of its officials. The monarchos and the hieropoioi are to dedicate phialai to several gods (lines 13). There are orders to elect epimenioi (lines 16-18) and orders for the treasurers to give them funds for various rituals (lines 18-20). Another fragmentary copy of the regulations is preserved in IG XII 4, 287.

\section{Cos. Law/decree about priestly personnel (polis) - second half of second century BCE $(I G$ XII 4,318$)$}

There is no prescript preserved, but there are officials mentioned (treasurers in lines 5, 14). There is a publication formula (lines 10-12) and a clause about payment for the stele (lines 12-15). The person who buys the priesthood of Nemesis and Adrasteia is to make three payments (lines 15-19). The cult appears to be public. In $I G$, this document is classified under "sales of priesthoods" (diagraphai). See Harris, "Toward a Typology" (2015), 56, for the difference between a law about contracts and a contract.

\section{Cos - Law/decree about priestly personnel (polis) - first century BCE (IG XII 4, 325)}

Ziehen rightly thinks that this is connected to the previous text; it is a later sale of the priesthood of Adrasteia and Nemesis. There is mention of a drawing up a diagraphe (contract) at B2. There is a fine for the priest who does not perform the sacrifice (line A13-16) and for others appointed (lines A17-20). The priest collects the fine (lines A22-5). In $I G$, this document is classified under "sales of priesthoods" (diagraphai); see also no. 160, above.

\section{Cos. Law/decree about priestly personnel (polis) - third century BCE (IG XII 4, 311c)}

The text is now completed by many other fragments included in $I G$, forming a contract for the sale of the priesthood of Asclepius, Hygieia and Epiona. There is a prescript in lines 1-9. There are officials mentioned (in Sokolowski: prostatai in line 2 , elected officials in line 5, poletai in line 11). See also no. 160, above. 


\section{Cos. Law/decree about priestly personnel (polis) - first century BCE (IG XII 4, 330)}

The prescript is missing, but this appears to be a measure of the polis, about the priestess of the goddess Nike, because kitharistai chosen by the people are mentioned (lines 26-27). This lays down rules about sacrifices (lines 1-4) and specifies what the priest who leads the procession of victors in contests should wear during the processions and for all other sacrifices (lines 4-14). There are rules about how to divide offerings between Nike and the priest (lines 17-21), about opening the treasury (lines 21-24), and about the kitharistai at the procession (lines 24-29). No penalties for officials are mentioned, but they may have been in the missing parts of the inscription. In $I G$, this document is classified under "sales of priesthoods" (diagraphar); see also no. 160, above.

\section{Cos. Law/decree about sacred matters (polis) - second half of second century BCE (IG XII 4, 342)}

This fragment is difficult to evaluate fully. It appears to contain rules about the perquisites of priests (lines 4,6 ) and the opening of the treasury (line 7). Civic officials appear to be mentioned (line 11).

\section{Cos. Calendar (polis) - ca. 158-138 BCE (Syll. ${ }^{3}$ 1028; IG XII 4, 281)}

This is part of a calendar for the gymnasium (names of month in lines A1, B1, C1). There is no enactment formula, no officials are named, and no penalty is mentioned, but the Council may be cited (line A22, so IG following Herzog; unless this refers to an assembly in the gymnasium itself, so von Prott, Hiller).

\section{Cos. Law/decree about priestly personnel (polis) - first half of first century BCE (Syll. ${ }^{3} 1012$; IG XII 4, 326)}

Lines 1-6 contain a form of prescript, and indicate the committee that wrote the rules. There are general provisions in the contract. In lines 16-20 there is a penalty for the failure to pay imposed and recorded by the prostatai and the treasurers. There is a provision for naming a substitute. The kyrios of the priestess or anyone can denounce anyone who wrongs the priestess. Half of the penalty goes to the accuser (lines 27-34). Lines 60-67 concern the perquisites of the priestess. The person who purchases the priesthood must pay one hundred 
(restored) drachmas a year for the temple and owe double if the payment is not made (lines 68-71). The document ends with a publication formula (lines 7174). In $I G$, this document is classified under "sales of priesthoods" (diagraphai); see also no. 160 , above.

\section{Cos. Law/decree about priestly personnel (polis) - first half of first century BCE (Syll. ${ }^{2} 597$; IG XII 4, 327)}

This fragment appears to contain rules about the sale of a priesthood, but the cult is unknown. In $I G$, this document is classified under "sales of priesthoods" (diagraphai); see also no. 160, above.

\section{Cos. Law/decree about sacred matters (polis) - end of second century BCE (Syll. ${ }^{3} 1000 ;$ IG XII 4, 293)}

As preserved, there is no prescript, but there are general rules about making sacrifices and providing feasts (skanopageisthon) by certain groups, often linked with economic activities. It is not clear what the purpose of these sacrifices is (see Sokolowski for discussion), but this should be a law of the polis because it refers to those purchasing public contracts to collect taxes and other fees (passim). There are no penalties mentioned in the fragment; an earlier side of the stele (A in $I G$ ), now erased, will have provided more information.

\section{Cos. Isthmos. Calendar (deme) - first half of second century BCE (IG XII 4, 280 a-c)}

These are three fragments (A-C) of the calendar of the deme of Isthmos; dates and deities are mentioned, as well as cultic rules. No penalties are mentioned.

\section{Cos. Isthmos. Signs (deme or sanctuary?) - beginning and end of third century BCE (IG XII 4, 359)}

An inscription, inscribed later in the first line, states that "a goat is sacrificed". There follows (lines 3-5) - but this text was inscribed earlier-a prohibition on certain items in the sanctuary; only the first item (line 5: himation) is preserved. Both inscriptions are signs. 
171. Cos. Isthmos. Dedication, citing a will, followed by cultic rules (private individual) - first half of second century BCE (IG XII 4, 349)

Pythion has dedicated a shrine to Artemis, Zeus of Suppliants, and his paternal gods (lines 1-3). Pythion and a priestess (probably his wife) have freed their slave Makarinos and dedicated him to look after the shrine (lines 3-12). Blessings are called on those who look after and make the shrine prosper (lines 12-14). The shrine is to remain the common property of Pythion's children. There are two rules about purity at the end (lines 16-17). From a legal perspective, this is related to a will (lines 11-12: kataleiper), which leaves property to the testator's sons, who are not to divide the property (lines 14-16).

172. Cos. Halasarna. Law/decree concerning priestly personnel (polis or deme?) - third or second century BCE (Syll. 621 ; IG XII 4, 303)

This is a regulation about the sale of a priesthood (lines $6-7,11$ ) and gives instructions about sacrifices on certain days (lines 1-4, 9-10); in $I G$, this document is also classified under "sales of priesthoods" (diagraphar), see also no. 160 above. There are public officials mentioned in lines 5-7 (napoiar). The document is fragmentary and, as preserved, does not have a prescript or mention any penalties.

\section{Cos. Halasarna. Decree with an order to inscribe a list (tribes) - ca. 180 BCE (Syll. 1023; IG XII 4, 103)}

This is a decree enacted by phylai and contains an enactment formula (lines 3, 18). It appears to be a one-off measure and is aimed at providing a complete list of those entitled to share in religious practices because the old list was illegible (lines 8-18). There are penalties for officials who do not carry out the task (lines 110-14). Though concerned with ritual participants, this is not a law about sacred matters.

\section{Cos. Halasarna. Decree with an order to inscribe a list (polis) - ca. $21 \mathrm{AD}$ (Syll. ${ }^{3}$ 793; IG XII 4, 365)}

There is a prescript (lines 1-3) with an enactment formula (line 9), ordering that the names of priests be inscribed because they have been illegally chiseled out 
(lines 9-14). This is a specific order, not a "sacred law", as it relates to recordkeeping and publication, not religious rituals.

175. Cos. Antimacheia. Law about priesthoods (polis or deme?) first half of third century BCE (Syll. ${ }^{3} 1006 ;$ IG XII 4, 356)

There is no enactment formula, only a set of rules about those serving as priestesses of Demeter. It gives the kyrioi of women the right to cast lots for sortition if the women are abroad (lines 1-4) and requires those selected to swear an oath (line 4). There is a rule about the perquisites of the priestesses (lines 10-13).

\section{Cos. Law/decree about sacred matters (polis) - end of fourth century BCE (IG XII 4, 333b)}

Sokolowski believed that this was part of the calendar of a deme. More cautiously, the editors of $I G$ classify it under decrees and other rules concerning sacrifices. Civic officials are mentioned in fragment a, not included in Sokolowski.

177. Cos. Dedication (private individual) and by-laws (private association) - around $300 \mathrm{BCE}$ and shortly afterward (Syll. 1106; IG XII 4, 348)

The stele contains a dedication by Diomedon to Herakles Diomedonteios (lines 1-4) followed by detailed cultic rules (lines 9-55). Diomedon also dedicates a slave and his offspring (lines 4-6) to supervise the cult. In somewhat later text (lines 56-68), further rites are specified and epimenioi are appointed to help the priest (of Herakles) administer the rites. Detailed by-laws of the familial association, called either hoi ek Diomedontos or hoi koinontes ton bieron, follow in a still later hand (lines 69-159). For some discussion, see Carbon and PirenneDelforge (2013), 68-70 etc.

178. Attica. Lamptrai. Law or sign (deme or other?) - around 400 $\mathrm{BCE}\left(I G \mathrm{I}^{3} 256\right)$

This is a regulation about the fee to be paid for those drinking from the spring Halykos in the deme of Lamptrai (lines 3-6). If the fee is not paid, one cannot 
drink (lines 6-7), and if one drinks without paying, one owes a fine of five drachmas (lines 7-9). If one takes away water without paying one obol per amphora, one must pay fifty drachmas sacred to the Nymphs (lines 9-12). There is no official mentioned. Whitehead (1986), 383, comments: "not demonstrably a deme document stricto sensu", though this remains possible.

\section{Attica. Athens. Fragment of law/decree about sacred matters (polis?) - fourth century BCE}

Meritt thought that the inscription concerned the Dipoleia celebrated on the 14 Skirophorion, but it is too fragmentary to allow any certainty.

\section{Paros. Dedication with a list of oracles (private individual) - third century BCE (SEG 15: 517)}

Sokolowski gives only the first nineteen lines of the inscription: a series of oracular responses given to the individual in question, Mnesipes. Mnesipes wished to honour the poet Archilochos of Paros (line 15) and thus consulted the oracle repeatedly. His request was eventually granted, and he founded an Archilocheion with altars for all of the gods and the hero Archilochos (lines 1619). There is no mention of the city. See Clay (2004) and Kimmel-Clauzet (2013).

\section{Lokris. Physkos. By-laws (private association) - second century CE (IGIX $\left.1^{2}, 670\right)$}

The inscription is the nomos of a (Dionysiac) thiasos, probably founded by a person called Amandos (line 1). There are rules in a casuistic form imposing a fine to the paid to the koinon (lines 11-13, lines 18-20; possibly 16-17 and 21-22) and another penalty in lines 16-17 for those who do not "go to the mountain."

Edward HARRIS

University of Durham

edward.harris@durham.ac.uk

assisted by Jan-Mathieu CARBON

University of Liège / University of Copenhagen

jmcarbon@ulg.ac.be / fpz408@hum.ku.dk 


\section{Abbreviations (numbers refer to inscriptions)}

Choix Delphes: Jacquemin, A., Mulliez, D. and Rougemont, R. (2012) Choix d'inscriptions de Delphes, traduites et commentées, Athens.

GHI: see Rhodes and Osborne (2013).

IE: Clinton, K. (2005) Eleusis, The Inscriptions on Stone, 2 vols., Athens.

IScM III: Avram, A. (1999) Inscriptions grecques et latines de Scythie Mineure, vol. III: Callatis et son territoire, Paris.

\section{Bibliography}

Ackermann, D. (2011) "Un nouveau type de communauté en Attique, Les pentékostyes du dème d'Aixone", in Badoud, N. ed. Philologos Dionysos, Geneva: 39-78.

Blok, J. (2014) "The Priestess of Athena Nike: a New Reading of IG I3 35 and 36", Kernos 27: 99-126.

Butz, P. (2010) The Art of the Hekatompedon Inscription and the Birth of the Stoikhedon Style, Leiden/Boston.

Carbon, J.-M. and Pirenne-Delforge, V. (2013) "Priests and Cult Personnel in Three Hellenistic Families", in Horster, M. and Klöckner, A. eds. Cities and Priests, Berlin/Boston: 65-119.

Cavanaugh, M.B. (1996) Eleusis and Athens: Documents in Finance, Religion and Politics in the Fifth Century B.C., Philadelphia.

Chandezon, C. (2003) L'élevage en Grèce (fin Véfin Ier s. a.C.), Bordeaux.

Chaniotis, A. (2009) "The Dynamics of Ritual Norms in Greek Cult", in Brulé, P. ed. La norme en matière religieuse en Grèce ancienne, Kernos Suppl. 21, Liège: 91-105.

Clay, D. (2004) Archilochos Heros: The Cult of Poets in the Greek Polis, Cambridge MA.

Deshours, N. (2006) Les mystères d'Andania, Bordeaux.

Dunand, F. (1973) Le culte d'Isis dans le bassin oriental de la méditerranée, vol. II: Le culte d'Isis en Grèce, Leiden.

Fröhlich, P. (2011) "La paradosis entre magistrats dans les cités grecques. Le dossier béotien", in Badoud, N. ed. Philologos Dionysos, Geneva: 183-229.

Gawlinski, L. (2012) The Sacred Law of Andania: A New Text with Commentary, Berlin/Boston. 
Kimmel-Clauzet, F. (2013) Morts, tombeaux et cultes des poètes grecs. Étude de la survie des grands poètes des époques archaïque et classique en Grèce ancienne, Bordeaux.

Harris, D. (1995) The Treasures of the Parthenon and Erechtheion, Oxford.

Harris, E.M. (2006) Democracy and the Rule of Law in Classical Athens, Cambridge/ New York.

Harris, E.M. (2008) “Two Notes on Legal Inscriptions”, ZPE 16: 81-84.

Harris, E.M. (2015) "Towards a Typology of Greek Regulations about Religious Matters: A Legal Approach”, Kernos 28: 53-83.

Harter-Uibopuu, K. (2002) "Strafklauseln und gerichtliche Kontrolle in der Mysterieninschrift von Andania (IG V 1, 1390)", Dike 5: 135-159.

Hedrick, C.W. (1990) The Decrees of the Demotionidai, Atlanta.

Lambert, S.D. (1998) The Phratries of Attica, 2nd ed. [1993] Ann Arbor.

Lambert, S.D. (2000) "The Sacrificial Calendar of the Marathonian Tetrapolis", ZPE 130: 43-70.

Lambert, S.D. (2002) “The Sacrificial Calendar of Athens”, BS A 97: 353-399.

Migeotte, L. (1992) Les souscriptions publiques dans les cités grecques, Geneva.

Migeotte, L. (2009-2010) "La fondation d'Attale II à Delphes: dispositions administratives et financières", Dike 12/13: 203-217.

Naiden, F.S. (2006) Ancient Supplication, Oxford.

Parker, R.C.T. (1996) Athenian Religion: A History, Oxford.

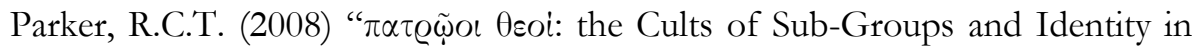
the Greek World”, in Rasmussen, A.H. and Rasmussen, S.W. eds. Religion and Society: Rituals, Resources and Identity in the Ancient Graeco-Roman World, Rome: 202-214.

Paul, S. (2013) Cultes et sanctuaires de l'île de Cos, Kernos Suppl. 28, Liège.

Peçirka, J. (1966) The Formula for the Grant of Enktesis in Attic Inscriptions, Prague.

Purvis, A. (2003) Singular Dedications: Founders and Innovators of Private Cults in Classical Greece, New York/London.

Reger, G. (2001) “The Mykonian Synoikism”, REA 103: 157-181.

Rhodes, P.J. and Osborne, R. (2003) Greek Historical Inscriptions, 404-323 BC, Oxford.

Rolley, C. (1965) "Le sanctuaire des dieux Patrôoi et le Thesmophorion de Thasos", BCH 89: 441-483.

Rousset, D., Camp, J. and Minon, S. (2015) “The Phokian City of Panopeus/ Phanoteus, Three New Rupestral Inscriptions, and the Cippus of the Labyadai of Delphi”, $A J A$ 119: 441-463. 
Rutherford, I. (2013) State Pilgrims and Sacred Observers: A Study of Theoria and Theoroi, Cambridge.

Schörner, G. and Goette, H.R. (2004) Die Pan-Grotte von Vari, Mainz.

Segre, M. (1951) "Rituali rodii di sacrifici”, PP 6: 139-153.

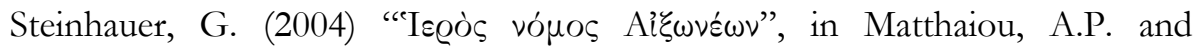

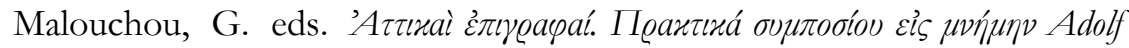
Wilhelm (1864-1950), Athens: 155-173.

Whitehead, D. (1986) The Demes of Attica, 508/7 - ca. 250 B.C., Princeton.

Wijma, S.M. (2014) Embracing the Immigrant, The participation of metics in Athenian polis religion (5th-4th century BC), Stuttgart.

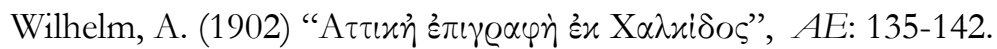

Wittenburg, A. (1990) Il testamento di Epikteta, Trieste. 